\title{
Duration of Crime Investigation Quandary under Ethiopian Criminal Justice System
}

\author{
Andualem Nega Ferede \\ School of Law, Hawassa University, Hawassa City, Ethiopia \\ Email: andualemnega@yahoo.com
}

How to cite this paper: Ferede, A. N. (2019). Duration of Crime Investigation Quandary under Ethiopian Criminal Justice System. Beijing Law Review, 10, 391-405. https://doi.org/10.4236/blr.2019.103023

Received: February 22, 2019

Accepted: May 5, 2019

Published: May 8, 2019

Copyright $\odot 2019$ by author(s) and Scientific Research Publishing Inc. This work is licensed under the Creative Commons Attribution International License (CC BY 4.0).

http://creativecommons.org/licenses/by/4.0/

\begin{abstract}
Justice is set in motion following the commission and report of an offence to the police targeting to initiation of crime investigation (CPC, 1961). Ethiopian laws do not locate when the investigation shall start. Though laws are silent, police officers may start inquiry at any time to set justice in motion in practice. After justice is set in motion through channels of crime reporting (CPC, 1961, Articles 11, $12 \&$ 19), the question of frequency and duration of investigation is under quandary since it is treated by different legislations differently. The 1961 Ethiopian criminal procedure code was the first document which dealt with the frequency and duration of investigation for the first time in Ethiopian criminal justice history. The FDRE constitution is the other document which locates the concept of duration of investigation at higher level. The Ethiopian criminal policy document envisaged different frequency and duration of crime investigation to be provided by law depending on the complexity and nature of the offence (FDRE Criminal Justice Policy, 2011). After the coming forth of this policy document, different legislations are enacted. The vagrancy control proclamation, the anti-terrorism proclamation, the new draft criminal procedure and evidence law are among the laws. These laws have intricacy concerning constitutionality, consistency and merit. Thus, the writer investigated these issues and analyzed the legislations with regard to the objectives of criminal justice policy.
\end{abstract}

\section{Keywords}

Duration, Criminal Investigation, Remand, Terrorism, Suspect, Vagrancy

\section{Introduction}

Crime is as old as human society and criminals are part of every society whether modern or primitive (Salman 2009). The term crime is defined in the Ethiopian 
criminal code as an act which is prohibited and made punishable by law (FDRE Criminal Code, 2004). It is an offence that is committed in the society and which is against the interest of the society that has been criminalized and punishable by law. The primary objective of the substantive criminal law and its adjective criminal procedure law is to maintain law and order in the society and hence to protect the life and liberty of people (Newburn, 2007). Hence, if the crime is committed, crime investigation is inevitable. Criminal investigation is the process of answering questions of "how, where, when, why and by whom" a crime was committed (Greenwood, 1979). It is a police activity directed toward the identification and apprehension of suspected offenders and the gathering, preservation and presentation of evidence regarding their alleged crimes (Caldwell, 1965). Criminal investigation is ensemble of methods by which crimes are studied and criminals apprehended (Encyclopedia Britannica, 2019). It requires investigating authorities to assemble evidence from various sources and directions to arrive at a coherent account of critical evidence. The official purpose of criminal investigation is to retrieve information that can be used as evidence in court of law (Karen \& Orthmann, 2010). The investigation process involves various personnel like the police officers, the prosecutor, accused person, arrested person, suspects, witness and the like. Criminal investigations are conducted primarily for identifying and bringing criminals to court of law. It helps to prevent crime and ensure peace and stability in the society. However, in the name of crime investigation, rights of individual should not be violated. Some people might think that law enforcement officials can do anything necessary to bring criminals to justice (Buckner \& Melton, 2010).

Adequate protection and promotion of all human rights and fundamental freedoms requires all government institutions to discharge an obligation of respecting human rights (UN Congress, 1990). State has an obligation under international human rights law to respect human rights (ICCPR, 1966). An obligation to respect human rights is simply refraining from interference in enjoyment of rights. Accordingly, any organ of government should refrain from any act that violates human rights. The 1995 of the FDRE constitution under article 13 (1) clearly indicates that the federal and state legislative, executive and judicial organs have the responsibility to respect and enforce fundamental rights and freedoms (FDRE Constitution, 1995). This requires all organs of government to discharge their duties in a way that does not violate human rights. Police, as part of the executive preventing and investigating crime, has an obligation to respect human rights. Criminal laws have an indispensable role in protection of human rights (Kaleck et al., 2007). In the administration of criminal justice, two things must strike a balance. Through the utmost effort of the justice machineries, crimes must be investigated and the truth must be revealed. At equal weight, the rights of the detainees must be well protected.

Human rights of suspects must be observed from the moment the investigation starts until the criminal proceedings have been completed as violation of rights during one stage has an effect on another stage (Lawyers Committee for 
Human Rights, 2000). The 1995 of FDRE constitution has explicitly recognized these rights as rights of arrested person, accused person, rights of persons held in custody and convicted person and prohibition against inhumane treatment. (FDRE Constitution, Articles 18, 19, 20 and 21, 1995) The laws should assist these efforts of the justice machineries with lucid and reasonable declaration of duration of investigation. Duration is the time frame in this scenario the period of time an investigation lasts (Microsoft Encarta, 2009).

But the law is not plain and the practice shows that suspects are detained for indefinite period of time without unpredictable procedure (CPC, 1961). Error of timing starts from the beginning since these laws do not locate when the investigation shall start. Despite the silence of the law when the investigation is launch, police officers may start at any time to set justice in motion. Duration of crime investigation is treated by different legislations. Ethiopian Criminal Policy envisaged different duration of crime investigation to be provided by law depending on the complexity and nature of the offence (FDRE Criminal Justice Policy, 2011). Following this policy document the anti-terrorism proclamation and vagrancy control proclamation bring forth the duration in different approach. The suspect of crime of terror remanded for the minimum of 28 days and a maximum of 4 months recurrence. The vagrancy control proclamation fixed the total duration of remand to be accomplished within 28 days. The criminal procedure law has already treated the issue to be administered within 14 days for indefinite frequency. The new draft criminal procedure envisaged different treatment based on the degree of the crime. Starting from the promulgation of these laws the constitutionality of the statutes, merits and demerits of these laws were controversial among members of legal academia and practitioners. The writer addressed this issue through analyzing the legislations in a comparative manner and assessing the practical situation in the research area.

\section{Laws of Crime Investigation and the Rights of the Arrested Persons in Regional \& International Instruments}

Among the international treaties which Ethiopia has ratified stated that everyone has the right to liberty and security of person. No one shall be subjected to arbitrary arrest or detention. No one shall be deprived of his liberty except on such grounds and in accordance with such procedure as are established by law. (ICCPR, Article 9(1), 1966) on the same issue the regional documents have the same clue regarding the rights of suspects. For instance African charter on human and peoples' rights under its article 6 declares that, every individual shall have the right to liberty and to the security of his person. No one may be deprived of his freedom except for reasons and conditions previously laid down by law. In particular, no one may be arbitrarily arrested or detained (ACHPR Article 6, 1981). Similarly, the American convention on human rights envisaged that every person has the right to personal liberty and security. No one shall be deprived of his physical liberty except for the reasons and under the conditions 
established beforehand by the constitution of the state party concerned or by a law established pursuant thereto. No one shall be subject to arbitrary arrest or imprisonment (ACHR, Article 7, 1969).

The European Convention on Human Rights is the only treaty that specifically enumerates the grounds which can lawfully justify a deprivation of liberty in the Contracting States. This list is exhaustive and "must be interpreted strictly". Everyone has the right to liberty and security of person. No one shall be deprived of his liberty save in the following cases and in accordance with a procedure prescribed by law: (Article 5). Among the justifiable grounds to deprive liberty of the suspect is the lawful arrest or detention of a person effected for the purpose of bringing him before the competent legal authority on reasonable suspicion of having committed an offence or when it is reasonably considered necessary to prevent his committing an offence or fleeing after having done so (ECPHR, Article 5(c), 1950).

Article 9(3) of the International Covenant on Civil and Political Rights, article 7(5) of the American Convention on Human Rights and article 5(3) of the European Convention on Human Rights provide that everyone detained shall be entitled to trial within "a reasonable time" or to release pending trial. This is a logical protection in view both of the fact that everyone charged with a crime has the right to be presumed innocent until proved guilty and of the fact that deprivation of liberty must be an exceptional measure (ICCPR, 1966; ACHR, 1969; ECPHR, 1950).

With regard to the right to trial within a reasonable time or to release pending trial guaranteed in article 5(3) of the European Convention, the European Court of Human Rights has held that "it is the provisional detention of accused persons which must not be prolonged beyond a reasonable time", and that the end of the period with which this provision is concerned is the day "on which the charge is determined, even if only by a court of first instance". It follows that it is not the day on which the judgment becomes final. Depending on the circumstances, however, the final date of the period to be taken into consideration may instead be the day of the accused's release after having deposited his security (ECHR, 1968).

The reasonableness of the time for deprivation of the rights of the suspect is the common concern for the above international and regional instruments. The European court of human rights tries to clarify the concept of reasonableness regarding time. The reasonableness of an accused person's continued detention must be assessed in each case according to its special features and the factors which may be taken into consideration are extremely diverse. There is consequently a possibility of wide differences in opinion in assessment of the reasonableness of a given detention (ECHR, 1968).

Accordingly, it falls in the first place to the national judicial authorities to ensure that the pre-trial detention of an accused person does not exceed a "reasonable time". To this end, they must examine all the circumstances arguing for and against the existence of a genuine requirement of public interest justifying, 
with due regard to the principle of the presumption of innocence, a departure from the rule of respect for individual liberty and set these out in their decisions on the applications for release (ECHR, 1968). It is essentially on the basis of the reasons given in these decisions and of the true facts mentioned by the detainee in his applications for release and his appeals that the Court is called upon to decide whether or not there has been a violation of a right. With regard to the meaning of the words "arbitrary arrest" in article 9(1), the Committee has explained that 'Arbitrariness' is not to be equated with 'against the law', but must be interpreted more broadly to include elements of inappropriateness, injustice, lack of predictability and due process of law. This means that remand in custody pursuant to lawful arrest must not only be lawful but reasonable in the circumstances. Remand in custody must further be necessary in all the circumstances, for example, to prevent flight, interference with evidence or the recurrence of crime" (ECHR, 1968).

The Human Rights Committee in the Mukong case ${ }^{1}$, made it clear that a detention on remand is legitimate under article 9(1) if it is "lawful and necessary" in the particular case. For instance article 5(1) (c) of the European Convention, too, foresees the possibility lawfully to detain a person "to prevent his fleeing after having" committed an offence.

In another case the African Commission held that the "indefinite detention of persons can be interpreted as arbitrary as the detainee does not know the extent of his punishment" article 6 of the African Charter had been violated in a case victims were detained indefinitely. (Communication No. 458/1991)

Furthermore, it constitutes an arbitrary deprivation of liberty within the meaning of article 6 of the African Charter to detain people without charges and without the possibility of bail. In a case against Nigeria the victims had been held in custody for over three years following elections (ACHPR, International Pen and Others v. Nigeria, Communication No. 137/94, 1998).

The persistence of reasonable suspicion that the person arrested has committed an offence is a condition sine qua non for the validity of the continued detention, but after a certain lapse of time, it no longer suffices. The Court must then establish whether the other grounds cited by the judicial authorities continued to justify the deprivation of liberty. Where such grounds are 'relevant'

${ }^{1}$ In the case of Mukong, the applicant alleged that he had been arbitrarily arrested and detained for several months, an allegation rejected by the State party on the basis that the arrest and detention had been carried out in accordance with the domestic law of Cameroon. The Committee concluded that article 9(1) had been violated, since the author's detention "was neither reasonable nor necessary in the circumstances of the case". For instance, the State party had not shown that the remand in custody was "necessary... to prevent flight, interference with evidence or the recurrence of crime" but had "merely contended that the author's arrest and detention were clearly justified by reference to" article 19(3) of the Covenant, which allows for restrictions on the right to freedom of expression. However, the Committee considered that "national unity under difficult political circumstances cannot be achieved by attempting to muzzle advocacy of multi-party democracy, democratic tenets and human rights", and that the author's right to freedom of expression had therefore been violated. Consequently, the Committee also concluded that the author's arrest and detention were contrary to article 9(1) of the Covenant. A. W. Mukong v Cameroon Communication No. 458/1991 (Views adopted on 21 July 1994), in UN doc. gaorA/49/40 (vol. II), p. 181 Para. 9.8. 
and 'sufficient', the Court must also ascertain whether the competent national authorities displayed 'special diligence' in the conduct of the proceedings (ECHR, Case of Assenov and Others v. Bulgaria, 1998).

\section{Duration of Crime Investigation and the Right of Arrested in Ethiopian Legal System}

\subsection{FDRE Constitution}

Ethiopia is a signatory member of the UN and the AU. It has ratified the UDHR, ICCPR \& ACHPR. The FDRE constitution protects the right to liberty. Accordingly, no one shall be deprived of his or her liberty except on grounds and procedure as are established by law. Arbitrary arrest and detention without a charge or conviction against any one is prohibited (FDRE Constitution, Article 17, 1995). All persons have an inalienable right to petition the court to order their physical release where the arresting police officer or the law enforcer fails to bring them before a court within the prescribed time and to provide reasons for their arrest. Where the interest of justice requires, the court may order the arrested person to remain in custody or, when requested remand him for a time strictly required to carry out the necessary investigation. In determining the additional time necessary for investigation, the court shall ensure that the responsible law enforcement authorities carry out the investigation respecting the arrested person's right to a speedy trial (FDRE Constitution Article 19(4), 1995). Persons arrested have the right to be released on bailunless it is infringed by special laws. In such prohibition they have the right to be brought before a court for possibility of release or evaluation of the progress of the investigators (FDRE Constitution Article 19(5), 1995).

\subsection{Criminal Procedure Code of Ethiopia}

The 1961 criminal procedure code of Ethiopia had followed the same arrangement like FDRE constitution. Where the police investigation yet not completed, the investigating police officer may apply for a remand for a sufficient time. The power to determine the duration and frequency of investigation is left for courts. The court before which the arrested person is brought as per article 29 of the code shall decide whether such person shall be kept in custody or be released on bail. If the right to bail is prohibited, the court may order the suspect to be remanded. No remand shall be granted for more than fourteen days on each occasion but for indefinite frequency (CPC Article 59, 1961). The suspect may apply for release on bail when he brought before a court. Any court to which an application for bail is made shall consider it without delay and shall call upon the prosecutor or the investigating police officer in his absence for comments and recommendations. It shall make its decision within 48 hours (CPC Article 66, 1961).

\subsection{Vagrancy Control Proclamation No. 384/2004}

Vagrancy Control Proclamation Article 6 empowers broad power to police. A 
police can arrest any person without warrant who may reasonably be suspected of being a vagrant. This vagrant suspect has no bail right. The investigating police officer who has arrested a person on suspicion of vagrancy shall complete his investigation and submit the investigation file to the public prosecutor within twenty-eight days after the arrest and the court to which a vagrancy case is filed shall give judgment within a maximum of a four-month period of time since the institution of the proceedings (Vagrancy Control Proclamation, No. 384, 2004).

\subsection{Ethiopian Anti-Terrorism Proclamation 652/2009}

Anti-Terrorism Proclamation 652/2009 under Article 20 declared that the court before which an arrested person is presented in accordance with Article 19 of the proclamation, may give an order to remand the suspect for investigation or trial. If the investigation is not completed, the investigating police officer may request the court for sufficient period to complete the investigation. Each period given to remand the suspect for investigation shall be a minimum of 28 days; provided however, that the total time shall not exceed a time span of four months. If a terrorism charge is filed in accordance with this Proclamation, the court shall order the suspect to be remanded for trial until the court hears and gives decision on the case (Ant-Terrorism Proclamation 652, 2009).

\subsection{The New Draft Criminal Procedure and Evidence Law of Ethiopia}

The new Draft Criminal Procedure and Evidence Law of Ethiopia under its article 124 stated different remand scenarios. For serious and medium level crimes it follows the same arrangement with the 1961 criminal procedure. If the court convinced that the investigation yet not completed and further investigation is mandatory, it may allow up to fourteen days of investigation save the suspect under custody. If the case is terrorism, the additional time for investigation might be extended up to 28 days for each occasion. Medium level crimes shall be probed within 28 days without possibility of extension. But for serious crimes and terrorism there is a possibility of further investigation for about four months (FDRE Draft Criminal Procedure and Evidence Law Article 124, 2009).

The new draft criminal procedure and evidence law brought a new concept within the Ethiopian criminal justice system. It introduced the special crime investigation technique in case the inquiry is impossible in the normal system. (Article 103) This special arrangement is functional to those crimes committed which impose duty to report on citizens (Article 64), money laundering, cyber crime, financing terrorism, crime of corruption, crimes related to custom duty and taxation (FDRE Draft Criminal Procedure and Evidence Law Article 103, 2009). In such cases the total period of remand shall not exceed two months. But if the public prosecutor applies for additional period of investigation, it might be extended for not more than a month (FDRE Draft Criminal Procedure and Evidence Law Article 107, 2009). 


\section{Comparative Analysis of Laws of Duration of Crime Investigation (Inconsistency, Issue of Constitutionality, Merit and Demerit)}

In Ethiopian criminal justice system if the commission of the crime is communicated to the police through channels of crime reporting i.e. compliant, accusation, flagrancy and police patrol, the police shall carryout the necessary investigation regardless of the nature of the crime and the modality of setting justice in motion. Investigating police officers shall carry out their duties despite their opinion that the accusation, complaint or information they have received is open to doubt (CPC Article 23, 1961). There is no law which governs when the police shall start investigation. As a result investigation may start at any time after the police received the information unless institution of charge is barred by statute of limitation. (CPC Articles, 42, 130) Once an investigation is started various laws of the country deal with the duration of investigation and the right of the suspect as it is pinpointed above. Duration of crime investigation is treated by federal democratic republic of Ethiopia constitution, criminal justice policy, and criminal procedure code of Ethiopia, anti-terrorism proclamation, vagrancy control proclamation, draft criminal procedure. The first law which prescribes the duration of investigation is the 1961 criminal code of Ethiopia. Constitutional level, it is only the 1995 constitution which stipulates duration of investigation (FDRE Constitution Article 19, 1995). Neither the imperial regime nor the Dergue regime constitutions declare regarding duration of investigation. Every investigation shall be completed without unnecessary delay. The modality of investigation might be pre-arrest or post arrest investigation. Post arrest investigation is more agonizing than the pre arrest investigation since it confines the liberty of the suspect. Thus it must be accomplished without unnecessary delay. Where a suspect is under arrest his interest in the speedy completion of the investigation is high. The Ethiopian legal regime follows two modality of duration of investigation. The federal democratic republic of Ethiopia constitution the 1961 criminal procedure and to some extent the new draft criminal procedure and evidence law had left the power to determine the duration of investigation for courts (FDRE Constitution Article 19, 1995).

The 1961 criminal procedure code under article 59 has pinpointed that courts have a power to give a maximum of 14 days within a single remand without specifying the total number of remand. The frequency and fixation of days with in a remand is left for courts. Courts can give from zero to fourteen days as per their discretion. They may assess the diligence, complexity of the case, and the private and public interest when they determine the duration of remand. Still they have the power to delimit or extend the frequency of remand if justice so requires. This power of courts reaffirmed under the 1995 constitution. Under article 19(4) where the interest of justice requires, the court may order the arrested person to remain in custody or, when requested remand him for a time strictly required to carry out the necessary investigation. In determining the additional time neces- 
sary for investigation, the court shall ensure that the responsible law enforcement authorities carry out the investigation respecting the arrested person's right to a speedy trial 19(4). These two laws follow the same rhythm empowering courts regarding the duration of investigation. Courts are trusted to enforce the rights of the suspect and balance the public interest.

Contrary to these, recently legislated laws treat the case in different manner. These laws snatched the traditional power of the courts to determine the duration of investigation given by the 1995 FDRE constitution and the 1961 criminal procedure code (FDRE Constitution Article 19(4), 1995 and CPC Article 59). The law maker seized the power to determine the duration of investigation, the minimum and maximum days of investigation and the total time a certain investigation shall took.

The anti-terrorism proclamation under article 20 declares that, courts before which an arrested person is presented may give an order to remand the suspect for investigation or trial. If the investigation is not completed, the investigating police officer may request the court for sufficient period to complete the investigation. Each period given to remand the suspect for investigation shall be a minimum of 28 days (Anti Terrorism Proclamation 652, 2009). The anti-terrorism proclamation follows the same approach with the draft concerning the total period of investigation, delimited the maximum duration of investigation within four months but without specifying the maximum duration of a single remand. The minimum duration of a single remand is for 28 days but it left the ceiling of a single remand to the discretion of the court. The only halt for the court is the four month period which could not be extended. Therefore a single duration of a certain adjournment for investigation may be extended up to 4 months. The vagrancy proclamation has similar remand time and total period of investigation. A person suspected of a crime of vagrancy shall be remanded for a single remand i.e. 28 days and investigating officers shall accomplish their investigation and institute charge to the maximum at the end of the $28^{\text {th }}$ day. There is no additional chance to extend the investigation.

Contrary to FDRE constitution and the 1961 constitution the law restricted not the ceiling of a single remand rather its minimum i.e. 28 days. A terror crime suspect, who is detained without reasonable suspicion or ascertained as he/she is an innocent person before the given time has lapsed, has no chance to be released free before 28 days. Courts have no power to minimize the detention to the lowest minimum they thinks fit. This legislation also delimited the total duration of investigation, which the total time not exceed a period of four months which might be against public interest where the type of the crime is complex and require extra time to investigate (Anti Terrorism Proclamation 652, 2009).

Similarly the Vagrancy Control Proclamation under its article 6(1) declared that any police may arrest without warrant any person who may reasonably be suspected of being a vagrant. Despite the petty nature of the offence vagrancy gained special emphasis. Article 6(3) stated that a person who is reasonably suspected of being a vagrant in accordance with Article 6(1) of this proclamation 
shall not be released on bail. Mere suspicion of commission of a crime of vagrancy entails the limitation of the fundamental right of bail and entitles police officers warrantless arrest (Vagrancy Control Proclamation No. 384, 2004). This provision is unconstitutional. It is only in special circumstances the constitution empowers the legislative to make laws which limit the right to bail (FDRE Constitution Article 19(6), 1995). From the very nature of pettiness, vagrancy could not qualify for "special circumstance" to restrict bail right. The investigating police officer who has arrested a person on suspicion of vagrancy shall complete his investigation and submit the investigation file to the public prosecutor within twenty-eight days after the arrest. This law prescribes a single 28 days remand which restricts the discretion of the court to narrow or extend the stay of the suspect considering the progress of the investigation. Police officers have no chance to request additional investigation time. The court has no power to prescribe additional investigation period. The legislative has pinpointed the maximum duration of a suspect charged with vagrancy to be accomplished within 28 days whatever the nature of the case is. The vagrancy proclamation limited not only the duration of investigation. Even courts which a vagrancy case is filed shall give judgment within a maximum of a four-month period of time since the institution of the proceeding (Vagrancy Control Proclamation No. 384, 2004). These prescriptions might have good contribution for speedy justice. But it harms the public interest in case the issue is complex and the investigating officers unable to address on the given time.

The new draft criminal procedure and Evidence law gave comprehensive power to the legislative organ to determine on the frequency of remand, duration of investigation and the maximum and minimum inquiry time and the total period. Unlike the special laws i.e. the anti-terrorism proclamation and the vagrancy control proclamation, the draft procedure and Evidence law treated all type of crimes through specifying the number of days a single remand shall took and the minimum and the maximum investigation time which is as per the prescription of the criminal justice policy of Ethiopia (FDRE Criminal Justice Policy, 2011). Accordingly for grave offenses and medium level crimes the law prescribes to the maximum 14 days period for a single remand. Depending on the progress of the investigation process, if the detention of the suspect so requires and the court convinced, the suspect might be remanded for a maximum of 14 days (124(1)). If the crime is related to terrorism the duration of a single remand might be extended up to 28 days (124(2)) (FDRE Draft Criminal Procedure and Evidence Law, 2009). This new draft procedure and evidence law concerning the duration of a single remand for medium level crimes follows the 1961 criminal procedure code approach i.e. it fixed a maximum of 14 days period for investigation. What makes different the total period of investigation must be completed within 28 days. In addition to this, the draft declared that for grave crimes and crimes of terror the number of days for investigation within a single remand extended to 28 days. Unlike the 1961 criminal procedure, the court has the power to give from 0 to 28 days for investigation. It broadens discretion power of 
courts through awarding additional 14 days within a single remand. Grave crimes and crimes of terror shall be investigated and completed within 4 months period. The law barred investigating officers from requesting additional period of investigation after four months (FDRE Draft Criminal Procedure and Evidence Law, 2009).

The anti terrorism law and the draft criminal procedure and evidence law treated terrorism through sending the suspect in to custody for about 28 days. But these two laws are differing since the draft says to the maximum of 28 days whereas the anti terrorism law stated to minimum of 28 days. In this regard the draft is better than the anti-terrorism proclamation at least it gives discretion for courts to count from zero to 28 days.

The drastic move within the draft proclamation is mainly related to medium level crimes. It stated that the total investigation period not to exceed 28 days (124(3)). Police is duty bound to frame charge after 28 days otherwise the suspect might be left free of charge. Another dire move with regarding to the new draft proclamation is concerning grave crimes and crimes of terror. Like anti-terrorism proclamation the total duration of investigation 124(4) for grave crimes and terrorism crimes shall not exceed 4 months. Limiting the total duration of investigation is the familiar practice in other legal systems like India and Netherlands; though it is the uncommon approach in Ethiopian criminal justice system. ${ }^{2}$ But other countries experience couldn't guarantee to challenge the supreme constitutional provisions. Another exceptional move of the draft is the introduction of "special crime investigation" concept. In such case the total period of remand shall not exceed two months. But if the public prosecutor applies for additional period of investigation, it might be extended for not more than a month. Therefore it abridged the general principle utmost to 3 months period (FDRE Draft Criminal Procedure and Evidence Law, 2009). Recent legislations had given special emphasis for terrorism and grave crimes which is also not uncommon in other legal systems. ${ }^{3}$

The new legislations approach in Ethiopia is very fundamental progress in protecting the right of the suspect and speedy justice. But the very motto of criminal justice system i.e. "striking a balance" between public and private interests might loss its balance. Limiting the investigation period may harm the pub-

\footnotetext{
${ }^{2}$ For instance in India, judicial custody may extend to a period of 90 days for a crime which entails a punishment of death, life imprisonment or period of imprisonment exceeding 10 years and 60 days for all other crimes if the magistrate is convinced that sufficient reasons exists Bhavani K. (2014). Laws of Custody in India: An Analysis of Section 167 of the Code of Criminal Procedure, 2014 In Netherlands legal system the total time spent in pre-trial detention may not exceed 110 days. (Government webpage, going to Court).

${ }^{3}$ In connection with arrests and detention under criminal legislation enacted to deal with acts of terrorism connected with the affairs of Northern Ireland, the European Court has explained that "in view of the difficulties inherent in the investigation and prosecution of terrorist-type offences, the 'reasonableness' of the suspicion justifying such arrests cannot always be judged according to the same standards as are applied in dealing with conventional crime. Nevertheless, the exigencies of dealing with terrorist crime cannot justify stretching the notion of 'reasonableness' to the point where the essence of the safeguard secured by Article 5(1) (c) is impaired" (ECHR, Case of Fox, Campbell and Hartley v. the United Kingdom, 1990).
} 
lic interest at large. In addition that putting the ceiling for investigation is unconstitutional in Ethiopian legal system since it is left for courts to be decided based on the nature of the case and diligence and competency of the investigators (FDRE Constitution Article 19, 1995).

In summary the anti-terrorism proclamation, the vagrancy control proclamation and the new draft criminal procedure and evidence law had gone beyond the spirit of the FDRE constitution. The legislature had done the courts job through fixing the minimum and maximum duration of investigation despite the constitution's approach is empowering the court to give reasonable period of investigation time considering the competency, diligence and progress of investigating officers and justice so requires. The Ethiopian criminal justice system lacks objectivity because of the laws promulgated without duly considering the constitution and balancing the public-private interests. The decision of European court of human rights affirmed that courts are real watchdogs in safeguarding the rights of citizens. ${ }^{4}$ It is courts as opposed to the legislature that would have an opportunity to see the real as opposed to hypothetical case and evaluate the application for additional time of investigation on the basis of the evidence provided by the suspect and the officers (Wondosen, 2012). On this regard the 1995 FDRE Constitution follow the appropriate approach through entrust the court to protect the rights of the suspect (FDRE Constitution Article 19, 1995). The responsibility to determine the time necessary to conduct investigation is given for courts. Courts are empowered to fix the right time for investigation. To do that court shall assess the interest of justice so requires the suspect to be remanded or left the custody conditionally or unconditionally. The court may order the arrested person to remain in custody if there is a possibility of release without further investigation. If the release of the suspect is non-probable because of the seriousness of the crime or other grounds established by the law, the court may remand him. But the remand is not a sloppy act of the court rather his stay in confinement is to secure better public interest and it should be for a time strictly required to carry out the necessary investigation (Wondosen, 2012). Courts during determining the additional time necessary for investigation, they shall ensure that the responsible law enforcement authorities carry out the investigation respecting the arrested person's right to a speedy trial. Contrary to this principle pinpointed under FDRE Constitution, subsidiary laws under discussion addressed the question of remand and the rights of the suspect in a different manner.

\section{Conclusion}

Legislators may fix roof of a single adjournment for investigation for the sake of administration of the right to speedy trial for the suspect. But they can't fix the minimum, frequency and the total duration of investigation haphazardly for the ${ }^{4}$ European court of human rights affirmed that the national judicial authorities are duty bound to ensure the pre-trial detention of an accused person not exceed a reasonable time (ECHR, 1968). 
following reasons. First: it is unconstitutional to delimit the minimum and the total duration of investigation. As per article 19(4) of FDRE constitution, the power to limit or extend the duration of investigation is left for courts. The legislative have no power to specify the minimum time condition of a single remand or to put a ceiling on the total number of days for investigation. The minimum 28 days limit makes impossible for the court to discharge its constitutional responsibility, i.e. enforcing the right to speedy justice. Though the court understands that less than the minimum allowed time is enough to investigate a certain case, it is required to remand the arrested for 28 days to the disadvantage of the suspect. The other option for the court in case remanding the terror suspect who could be investigated is less than the allowed minimum, rejecting the request of officers to remand the suspect and let the suspect free. This action has prejudicial effect on the public. Therefore, empowering the law enforcement organs to determine the duration of the suspect would not serve the interest of justice. By virtue of article 9(1) of FDRE constitution, article 20(3) of the anti-terrorism proclamation should not have force of law (FDRE Constitution, 1995).

Second: this haphazard fixation of days has an adverse effect on the rights of the suspect too. Suspects are not required to wait for a lapse of 28 days to get the floor of the court. For silly and unfounded police cases, the best solution for suspects is to have court access within a short period of time. The previous 14 days period pinpointed under the criminal procedure code which is much better than keeping them for 28 days. Especially in Ethiopian criminal justice system, there is no law which forces the investigating officers to bring the suspect before a court if he finalizes the investigation before the lapse of the day fixed by the court. Suspects are required to detain and kept silent till the arrival of the day pronounced by the court to have a court access. The problem may worsen if the court is not competent and independent from other bodies. They might allow unnecessary time simply requested by the officers. Therefore the duration of investigation will be much better for the suspect if it is tapered.

Third: the ceiling of total duration has an adverse impact on the public interest. Especially in crimes like terrorism and grave crimes, the commission of the crime is well planned and very complicated. In the modern world the commission of crime is very sophisticated which require special competence and sufficient time to investigate. Put a limit on the total duration of investigation may help the investigating officers and prosecution organs to do their job diligently. But sometimes because of the nature of the crime and criminals, it may not possible to accomplish within the time limit set by the legislature. To keep the promise of the legislator, officers are obliged to release the most probable criminals on the reason of time.

Fourth: predator criminals and their advocates may focus on time rather than merit to escape from justice. The time game is very helpful for them to escape from justice.

Fifth: the problem concerning the 1961 criminal procedure code approach which allows successive remand in custody may have a prejudicial impact on the 
rights of the suspect. Requesting him to attend successive court remands has a distress for him. In such case the British model is very helpful. In recognition of the fact that unsatisfactory of successive remands in custody and the necessity of the accused's presence at each remand (the period of remand must not exceed eight days) the criminal justice act 1982 introduced a clue to allow the accused to consent to being remanded in custody for up to a 28 days without attending the court. If the magistrates have a possibility of adjournment they must inform him or his legal representative further remands is being made in his absence. If and only if he consents they may then remand him thrice without his being brought to court. On the fourth occasion he must attend whether he wishes or not (British Criminal Justice Act, 1982). The criminal justice act 1988 inserted a new section to relieve prison service the task of bringing remandees to the court when no useful purpose could possibly be served by bringing remandees to the court; the magistrate is empowered to remand an accused in custody for up to 28 clear days whether or not he consents (British Criminal Justice Act, 1982).

The laws didn't assist the efforts of the justice machineries with lucid and reasonable declaration of duration of investigation. Laws are not plain and the practice shows that suspects are detained for indefinite period of time without unpredictable procedure (CPC, 1961). Error of timing starts from the beginning since these laws do not locate when the investigation shall start. Some police officers start the investigation immediately as they receive crime report others begin after hours, days or weeks. Suspects of terror and grave crimes detained for indefinite period without charge.

\section{Conflicts of Interest}

The authors declare no conflicts of interest regarding the publication of this paper.

\section{References}

ACHPR (African Charter on Human \& Peoples Right) (1998). Constitutional Rights Project and Civil Liberties Organization v. Nigeria, Communication No. 102/93, Decision Adopted on 31 October 1998, Para.

http://www1.umn.edu/humanrts/africa/comcases/102-93.html

ACHPR (African Charter on Human and Peoples' Rights) (1981). Article 7. Adopted 27 June 1981, Entered into Force 21 October 1986.

ACHR (American Convention on Human Rights) (1969). Article 5 \& 8. Opened for Signature and Ratification on 22 November 1969, Entered in to Force on 18 July 1978.

Anti-Terrorism, Proclamation No. 652/2009 (2009). 15th Year No. 57. Addis Ababa, 28th August, 2009.

British Criminal Justice Act. (1982).

Buckner, F., \& Melton, Jr. (2010). Criminal Justice-The Law. InfoBase Publishing.

Caldwell, R. G. (1965). Criminology (2nd ed.).

CPC (Criminal Procedure Code of Ethiopia) (1961). Proclamation No. 185 of 1961 Im- 
perial Ethiopian Government. Addis Ababa: Authority of the Ministry of Pen.

ECHR (European Court of Human Rights) (1968). Wemhoff Case v. the Federal Republic of Germany (p. 22, para. 5 and p. 23, para. 9). Judgment of 27 June 1968, Series A, No. 7.

ECHR (European Court of Human Rights) (1998). Case of Assenov and Others v. Bulgaria (p. 3300, Para. 154). Judgment of 28 October 1998, Report 1998-VIII.

ECPHR (European Convention for the Protection of Human Right and Fundamental Freedoms) (1950). Article 5 \& 6. Adopted on 4 November 1950 by the Council of Europe and Entered in to Force on 3 Many 1953.

Encyclopedia Britannica (2019). Criminal Investigation. https://www.britannica.com

FDRE (2004). Criminal Code of the Federal Democratic Republic of Ethiopia. Federal Negarit Gazzeta.

FDRE (Federal Democratic Republic of Ethiopia) Constitution (1995). Proclamation No. 1. Negarit Gazetta, Year 1, No 1.

Federal Democratic Republic of Ethiopia, FDRE (2009). Draft Criminal Procedure and Evidence Law. Addis Ababa.

Federal Democratic Republic of Ethiopia, FDRE (2011). Criminal Justice Policy. Addis Ababa.

Greenwood, P. W. (1979). The Rand Criminal Investigation Study: Its Finding and Impacts to Date 13.

Hess, K. M., \& Orthmann, C. H. (2010). Criminal Investigation (9th ed.). Delmar: Cengag Learning.

ICCPR (International Covenant on Civil and Political Rights) (1966). Adopted by United Nations General Assembly, on 16 December 1966, Entered into Force 23 March 1976.

Kaleck, W. et al. (2007). International Prosecution of Human Rights Crimes. Berlin, Heidelberg: Berlin Verlag.

Lawyers Committee for Human Rights (2000). What Is a Fair Trial? A Basic Guide to Legal Standards and Practice.

Microsoft Encarta (2009). 1993-2008 Microsoft Corporation.

Newburn, T. et al. (2007). Handbook of Criminal Investigation.

Salman, R. K. (2009). Rights of Accused Person under Nigerian Criminal Justice System: A Need for Improvement.

United Nations Congress (1990). Basic Principles on the Role of Lawyers Adopted by the Eighth United Nations Congress on the Prevention of Crime and the Treatment of Offenders. Havana, 27 August to 7 September 1990-Preamble.

Vagrancy Control Proclamation No. 384/2004. (2004). 10th Year No. 19, Addis Ababa, 27th January 2004.

Wondosen, D. (2012). Ethiopian Criminal Procedure. School of Law Addis Ababa University. 